\title{
Obtainment of embryogenic cell suspensions from scalps of the banana CIEN-BTA-03 (Musa sp., AAAA) and regeneration of the plants
}

\author{
Maribel Ramírez-Villalobos* \\ Laboratorio de Cultivo de Tejidos \\ Instituto de Investigaciones Agronómicas \\ Departamento de Botánica \\ Facultad de Agronomía \\ Universidad del Zulia \\ A.P. 15205 , ZU4005, Venezuela \\ Tel: 582617596184 \\ Fax: 582617596184 \\ E-mail: mcramire@cantv.net \\ Eva de García \\ Laboratorio de Biotecnología Vegetal \\ Centro de Botánica Tropical \\ Instituto de Biología Experimental \\ Facultad de Ciencias \\ Universidad Central de Venezuela \\ Los Chaguaramos, Caracas 1041, Venezuela \\ Tel: 582617596184 \\ Fax: 582617596184
}

Financial support: Fundación UCV (FUCV) through the Project No. 0297/2006 and Academic Vicerectorate of the University del Zulia, for the Grant for Graduate Studies in Botany, Facultad de Ciencias, Universidad Central de Venezuela.

Keywords: bananas, embryogenic callus, embryogenic cell suspension, Musa sp, plant regeneration, scalp, secondary somatic embryogenesis.

Abbreviations: 2.4-D: 2.4-dichlorophenoxiacetic acid
BA: benzyladenine
CE: conversion of embryos
CNEC: compact non-embryogenic calluses
ECS: embryogenic cell suspension
ES: explants with scalps
IAA: indoleacetic acid
ME: mature embryos
MM: maturation medium
MS: Murashige and Skoog medium
NECS: non-embryogenic cell suspension
NNEC: nodular non-embryogenic calluses
NS: number of scalps cm of the multiple meristem mass
PSE: primary somatic embryos
SCV: sedimented cell volumen
VP: percentages of vitroplants thus obtained.

The purposes of this work were to obtain embryogenic cell suspensions (ECS) from scalps and to regenerate plants of the banana CIEN-BTA-03. Shoot apexes were grown in the scalp-induction medium of Murashige and Skoog plus BA and IAA, following four diverse treatments. The first two, ME22 and ME25, were solid media supplemented with $\left(\mathrm{mg} \mathrm{L}^{-1}\right)$ 22.7 BA plus 0.192 IAA, and 25 BA plus 0.217 IAA, respectively, all containing $1.8 \mathrm{~g} \mathrm{~L}^{-1}$ of phytagel, and subcultures were performed monthly and bimonthly over 16 months. The other two treatments, IT22 and IT25, resembled ME22 and ME25 but consisted in temporary immersion for four months without subcultures, followed by two months in solid media. The scalps were grown in callusinduction medium and embryogenic calluses were obtained with abundant somatic embryos, especially in scalps from IT25. About 10 to 15 embryos from each were transferred to $5 \mathrm{ml}$ of multiplication medium to initiate the ECS. The scalps obtained from the IT25 treatment were the most successful as they led to ECS with high embryogenic capability. In addition, IT25 decreased the timespan required for the production of scalps. The obtained ECS gave rise to secondary somatic embryos. It showed a high multiplication index, as well as numerous mature somatic embryos, and good conversion of embryos and plant regeneration.

*Corresponding author 
The bananas belonging to the Cavendish subgroup are the most cultivated around the world and they represent and important source of jobs and income for the exporting countries, mainly in Latin America and the Caribbean, as well as in Africa and Asia. In 2005 this crop occupied about 34.000 ha in Venezuela, yielding 15.3 ton ha $^{-1}$ which meant an overall production of 520.000 ton and the worldwide $23^{\text {rd }}$ position, as it represented $4,9 \%$ of the total (Agrocadenas, 2005).

All the commercial varieties grown in Venezuela are susceptible to the Sigatoka disease, both black (Mycosphaerella fijiensis) and yellow (M. musicola), a condition that has led to great losses in fruit production. This renders it necessary to obtain resistant or tolerant clones to those diseases. The genetic improvement of bananas through classical methods is limited by the long timespans for regeneration, high sterility and polyploidy in these cultivars. To overcome such restrictions newer biotechnological tools ought to be applied, such as gene transfer and somaclonal variations (Giménez et al. 2001), as well as procedures for massive production of clones of such improved plants, like somatic embryogenesis, which represents an ideal method for gene transfer.

Success of the use of those methods relies on, among other factors, reproducible techniques and efficiency in the induction of shoots and somatic embryos. The lack of regeneration procedures is often the main obstacle to the application of modern biotechnology, including gene transfer (Caboni et al. 2002; Jalil et al. 2003). The selection of promising tissues from banana plants for genetic engineeringis restricted to meristem tissues and embryogenic cell suspensions; the low rates of transformations of explants isolated from the growth of multiple meristems indicates that this tissue is not the best choice for genetic transformations. Instead, the transformation of cells in embryogenic suspensions from bananas and plantains has proven to be very efficient
(Houllou et al. 2005).

The present work was carried out with explants from the somaclonal variant CIEN- BTA-03 that is resistant to black Sigatoka, and which was obtained through adventitious shoots-induction with $15 \mathrm{mg} \mathrm{L}^{-1}$ BA from in vitro plants of Williams banana, a cultivar affected by the Sigatoka disease. Several researchers have shown differences at the biochemical (Vidal and de García, 2000) or cytogenetic and genetic (Giménez et al. 2001) levels, between CIEN-BTA03 and its parental clone Williams. A cluster analysis performed by Giménez et al. (2001) using RAPD markers ratified the genetic differences between the somaclonal variant CIEN-BTA-03 and its parental Williams cultivar. Additionally, comparison of the features of fruits from the former with those from its parental clone revealed that CIEN-BTA-03 shows better sensory than the latter (Unai et al. 2004). Moreover, agronomic analyses (Trujillo et al. 1998) showed that bunches of fruits from somaclone CIENBTA-03 were heavier (average $35 \mathrm{~kg}$ ) than those from Williams clone (average $31 \mathrm{~kg}$ ).

There are diverse kinds of explants for the establishment of ECS from Musa, among them the scalps obtained from the upper portion (roughly $3 \mathrm{~mm}$ ) of multiple meristems. The latter are grown from shoot apexes in induction-media containing cytokinins and auxins. The transfer of the embryogenic calluses derived from scalps into a liquid growth-medium allows to establish the ECS. Among the advantages of using scalps are that no frequent field-trips are required, unlike other methods (for instance, to collect immature flowers), and that the embryogenic response does not rely on time or seasons and this provides a useful tool to control the quality of the whole process (Strosse et al. 2006).

Somatic embryogenesis at a large scale, throughout repeated cycles of secondary embryogenesis and preferably in liquid media appears to be the most promising method

Table 1. Mean percentages of explants with scalps (ES) and number of scalps per $\mathrm{cm}^{2}$ (NS) of mass of multiple meristems obtained from shoot apexes of CIEN-BTA-03, under various culture conditions and in diverse BA or IAA concentrations.

\begin{tabular}{|c|c|c|c|c|}
\hline Treatment & Conditions & BAlIAA $\left(\mathbf{m g ~ L}^{-1}\right)$ & ES (\%) & NS \\
\hline TI25 & $\begin{array}{c}\text { Temporary immersion (4 months) } \\
\text { solid (2 months) }\end{array}$ & $25 / 0.217$ & $38.8 \mathrm{a}$ & $46 \mathrm{a}$ \\
\hline TI22 & $\begin{array}{c}\text { Temporary immersion (4 months) } \\
\text { solid (2 months) }\end{array}$ & $22.7 / 0.192$ & $27.5 \mathrm{c}$ & $28 \mathrm{c}$ \\
\hline ME25 & Solid medium (16 months) & $25 / 0.217$ & $33.7 \mathrm{~b}$ & $33 \mathrm{~b}$ \\
\hline ME22 & Solid medium (16 months) & $22.7 / 0.192$ & $21.3 \mathrm{~d}$ & $16 \mathrm{~d}$ \\
\hline
\end{tabular}

For each variable, means followed by different small letters indicate statistically significant differences $(P<0.05)$. 

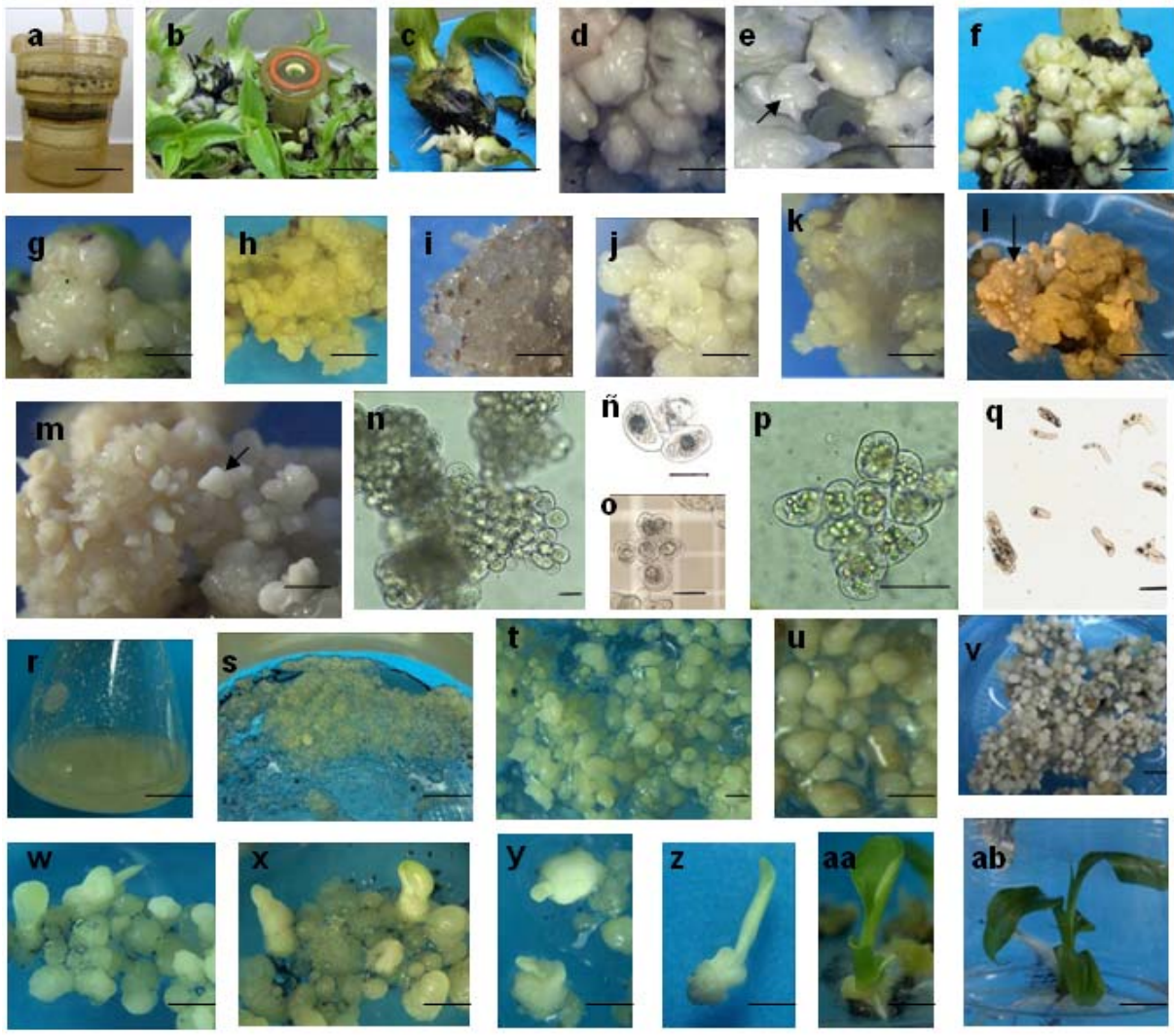

Figure 1. Somatic embryogenesis derived from scalps of the banana CIEN-BTA-03.

(a) Temporary immersion system.

(b-c) Multiple meristems at the base of the shoots after 4 months in (a).

(d-e) Multiple small meristems (1-3 mm, arrow) coming from (b) and after two months in ME25.

(f-g) Tissue features after 16 months in ME22 or ME25; note the formation of multiple meristems of diverse sizes.

(h-i) Non-embryogenic calluses; nodular ones were frequent in all explants whereas compact ones were rare after 5 months.

(j-k) Primary somatic embryos (SE) developed from scalps from TI25, at 3.5 months.

(I-m) Embryogenic callus with numerous SE (arrow) on its periphery, adequate for the establishment of ECS.

(n) Predominant embryonic cells aggregate in the ECS, at two months.

(ñ-o) Embryogenic cell.

(p) Cell aggregate consisting of parenchymatous cells with starch granules, highly frequent in NECS, at two months.

(q) Non-embryogenic cells in NECS, at 16 days.

(r) ECS, at four months.

(s-u) SE in maturation-medium, at 20 days (s-t) and 30 days (u).

( $v-z)$ SE in embryo-conversion medium, at one month.

(aa-ab) Regenerated plantlet in MS plus $400 \mathrm{mg} \mathrm{L}^{-1}$ of BA, at 21 days and 1.5 months, respectively, coming from (U).

(a) $\mathrm{Bar}=45 \mathrm{~mm}$.

(b, f, l, s, ab) Bar $=10 \mathrm{~mm}$.

(c, h, aa) Bar $=5 \mathrm{~mm}$.

(d, i-k, m) Bar $=1 \mathrm{~mm}$.

(e, g, t-u) Bar $=2 \mathrm{~mm}$.

(n, p-q) Bar $=100 \mu \mathrm{m}$.

(ñ-o) $\mathrm{Bar}=50 \mu \mathrm{m}$.

(r) $B a r=22 \mathrm{~mm}$.

(v-z) Bar $=2,5 \mathrm{~mm}$.

for the massive cloning of plants, as great numbers of embryos may be produced over short timespans and limited volumes of media, and possibly mechanized (Choi et al. 2002; Ramakrishnan and Dutta, 2006). Secondary embryogenesis is a process whereby the new somatic embryos are initiated from primary (somatic) or originallyformed embryos (Martinelli et al. 2001; Khalil et al. 2002; Kuo et al. 2005). Also, in many species explants efficiency of primary embryogenesis is lower than the secondary one (Ramakrishnan and Dutta, 2006).

Thus, the present study was aimed at the obtainment of embryogenic cell suspensions starting with scalps of the CIEN-BTA-03 banana variant. The morphological features of the tissues were analyzed and followed until the formation of new plants, while ascertaining the growth 


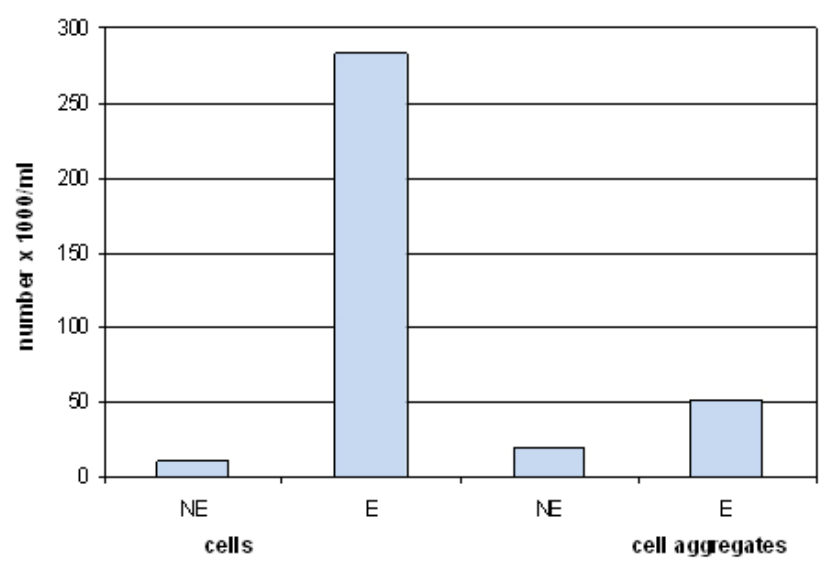

Figure 2. Numbers of cells and of cell aggregates in embryogenic cell suspension I, after two months. E: embryogenic; NE: non-embryogenic.

kinetics of the cell suspensions and the regeneration of plantlets from those somatic embryos.

\section{MATERIALS AND METHODS}

\section{Plant material}

Plant material for this research was obtained from CIENBTA-03 banana vitroplants (from a fourth subculture cycle), grown for 8 weeks in Murashige and Skoog (MS) (1962) medium additionally containing $30 \mathrm{~g} \mathrm{~L}^{-1}$ sucrose, vitamins as in Morel and Wetmore (1951), $2.5 \mathrm{mg} \mathrm{L}^{-1}$ bencyladenine (BA) and $7 \mathrm{~g} \mathrm{~L}^{-1}$ agar. The vitroplants were incubated in small glass vials $(6.5 \times 5.5 \mathrm{~cm})$ with $30 \mathrm{ml}$ of medium, continuous fluorescent white light $\left(33 \mu \mathrm{mol} \mathrm{m} \mathrm{m}^{-2}\right.$ $\left.{ }^{1}\right)$ at $25 \pm 1{ }^{\circ} \mathrm{C}$. Media $\mathrm{pH}$ was adjusted to 5.8 prior to sterilization at $121^{\circ} \mathrm{C}$ and $1.1 \mathrm{~kg} \mathrm{~cm}^{-2}$ for $20 \mathrm{~min}$.

\section{Induction of scalps}

Shoot apexes $(8 \mathrm{~mm}$ high by $1.5 \mathrm{~mm}$ diameter) were extracted from the vitroplants and grown in the scalpinduction medium consisting of MS plus BA and IAA, under four regimes or treatments. The first two, ME22 and ME25, were solid media supplemented with $\left(\mathrm{mg} \mathrm{L}^{-1}\right) 22.7$ BA plus 0.192 IAA or 25 BA plus 0.217 IAA, respectively, all also containing $1.8 \mathrm{mg} \mathrm{L}^{-1}$ of phytagel, and $\mathrm{pH}$ 6.2. Four monthly subcultures and afterwards bimonthly for 16 months, were carried out in both treatments. For this, the upper portions (about $3 \mathrm{~mm}$ ) of the small white globular structures (of less than $10 \mathrm{~mm}$ ) (i.e., the multiple meristems formed at the base of the explants) or from the shoots grown by these were removed, taking care to discard foliar or rhizome tissue.

The other two treatments were based on growing shoot apexes kept temporarily immersed in concentrations of growth regulators corresponding to ME22 or ME25, henceforth named TI22 and TI25, respectively, throughout four months without subcultures and adding fresh medium once monthly. Each flask contained $200 \mathrm{ml}$ of medium, and immersion periods were 30 min every $8 \mathrm{hrs}$. Afterwards, the tissues were transferred to solid media for two months until small meristems ( 1 to $3 \mathrm{~mm}$ in diameter) were obtained. Explants (from the four treatments) were kept at an irradiance of $5 \mu \mathrm{mol} \mathrm{m}^{-2} \mathrm{~s}^{-1}$ at $26 \pm 1^{\circ} \mathrm{C}$.

\section{Induction of somatic embryogenesis}

Upper portions or scalps ( 2 to $3 \mathrm{~mm}$ ) of tissue form small multiple meristems (see above) were excised under a stereoscopic microscope and grown in an embryogenesisinduction medium Zs prepared by diluting the MS salts to one-half and adding $1 \mathrm{mg} \mathrm{L}^{-1}$ 2.4-dichlorophenoxiacetic acid (2.4-D), $0.219 \mathrm{mg} \mathrm{L}^{-1}$ zeatin and $1.8 \mathrm{~g} \mathrm{~L}^{-1}$ phytagel, and $\mathrm{pH}$ 6.2. Explants were kept in darkness at $26 \pm 1^{\circ} \mathrm{C}$ until the formation of embryogenic calluses.

\section{Establishment and maintenance of cell suspensions}

Ten to 15 embryos from each embryogenic callus were transferred to $5 \mathrm{ml}$ of multiplication medium $\mathrm{Zl}$ (= liquid $\mathrm{Zs}$ ) in $25 \mathrm{ml}$ Erlenmeyer flasks, and attached to an orbital shaker at $100 \mathrm{rpm}$, under darkness and $26 \pm 1^{\circ} \mathrm{C}$ for two months; this procedure led to the embryogenic cell suspension I (ECS I) which was then filtered through a metallic mesh ( $250 \mu \mathrm{m}$ pore size) to establish ECS II. The growth kinetics of the latter suspension was followed over 16 days. ECS II was initiated in $150 \mathrm{ml}$ Erlenmeyer flasks containing $20 \mathrm{ml}$ of medium, $1.38 \%$ of sedimented cell volume (SCV) and $30 \%$ of suspension media, under the conditions just described above.

Also, non-embryogenic cell suspensions (NECS I and II) were prepared following the same criteria as for ECS I and II, respectively, starting NECS I with $100 \mathrm{mg}$ of nodular calluses in $5 \mathrm{ml}$ of solution. After seven or twelve days, $50 \%$ of the incubation media was replaced in suspension I or II, respectively, and visible yellow globular structures greater than $1 \mathrm{~mm}$ were discarded from the ECSs, and necrotic tissue was removed from the NECSs.

\section{Maturity and conversion of somatic embryos}

After two months of growth $1 \mathrm{ml}$ aliquots of sedimented cells and embryogenic aggregates (smaller than $1 \mathrm{~mm}$ ) were transferred from both ECS I and ECS II into maturation medium (MM) prepared as Zs without growth regulators, at $\mathrm{pH}$ 5.8. After a further month the mature embryos were transferred to an embryo-conversion medium (CM), MM plus $0.2 \mathrm{mg} \mathrm{L}^{-1} \mathrm{BA}$ and $2 \mathrm{~g} \mathrm{~L}^{-1}$ phytagel. As soon as the embryos emitted their shoot or first foliar sheath (20 to 30 days) they were placed in a growing plant medium (GM), based on MS plus $400 \mathrm{mg} \mathrm{L}^{-1} \mathrm{BA}$ and $7 \mathrm{~g} \mathrm{~L}^{-}$ ${ }^{1}$ agar. 


\section{Experimental setup, variables and statistical analyses}

The experimental setup was entirely at random. In the stages of scalp- and callus-induction 20 replicates per treatment and four experimental units per replicate were used. The temporary immersion procedure comprised two replicates with five explants each, and cell suspensions had three replicates. The following values were determined: percentages of explants with scalps (ES), number of scalps $\mathrm{cm}^{-2}$ of the multiple meristem mass (NS), $\%$ of scalps with primary somatic embryos (PSE), or with embryogenic callus (EC), nodular non-embryogenic calluses (NNEC) or compact non-embryogenic calluses (CNEC).

The growth kinetics of the cell suspensions was followed over 16 days. Every second day the following values were measured: fresh and dry weight, numbers of embryogenic cells and aggregates (both embryogenic and nonembryogenic), and numbers total cells per $\mathrm{ml}$ of medium. Weights were determined in three $500 \mu \mathrm{l}$ samples from each flask; fresh weight was measured as the sediment of the aliquots after $10 \mathrm{~min}$ centrifugation at $14.000 \mathrm{rpm}$, while the dry weight corresponded to the same sediments after drying at $60^{\circ} \mathrm{C}$ for $48 \mathrm{hrs}$. Cell counts were made on three $150 \mu \mathrm{l}$ aliquots from each flask and four replicates of each; counting was performed with a Neubauer camera.

At the stage of maturity and somatic embryo conversions we determined the numbers of mature embryos (ME) in the sediment of embryogenic cells and aggregates from ECS I and II, and the percentages of conversion of embryos (CE) and those of vitroplants thus obtained (VP). Analyses of the variables $\mathrm{ES}, \mathrm{NS}, \mathrm{ME}, \mathrm{CE}$ and VP were carried out using the univariant general linear model (GLM) of the SPSS ${ }^{\circledR}$ program (Statistical Package for the Social Sciences) as recommended by Pérez (2005).

\section{RESULTS AND DISCUSSION}

\section{Scalp induction}

The highest percentage of explants with scalps $(38.8 \%)$ and the maximum number of scalps $\left(46 \mathrm{x} \mathrm{cm}^{-2}\right.$ of the mass of multiple meristems) were obtained by growing the shoot apexes under temporary immersion (for four months) in the MS medium plus $25 \mathrm{mg} \mathrm{L}^{-1} \mathrm{BA}$ and $0.217 \mathrm{mg} \mathrm{L}^{-1} \mathrm{IAA}$, followed by two months in a similar though solid medium (TI25, Table 1). In contrast, the tissues grown in solid media (ME22 or ME25), with four monthly subcultures and then bimonthly changes rendered less multiple meristems after 16 months.

The establishment of ECS from commercial variants of Musa spp. is restricted by the short availability of embryogenically competent explants, due to partenocarpy. In view of this, somatic embryogenesis is usually based on immature male (Filippi et al. 2001; Houllou et al. 2005; Pérez and Rosell, 2008) or female (Grapin et al. 2000) flowers, shoot apexes or multiple meristems (Xu et al. 2005; Strosse et al. 2006) and long periods are required to prepare the tissues for the induction of the process.

Our treatment TI25 may be regarded as an important and useful alternative for the production of large numbers of multiple meristems of banana over six months and a single subculture, as no further subcultures are required, decreasing production costs. In contrast, Strosse et al. (2006) had reported that the monthly subculture cycles in solid media (MS plus $22.73 \mathrm{mg} \mathrm{L}^{-1} \mathrm{BA}$ and $0.175 \mathrm{mg} \mathrm{L}^{-1}$ IAA) ranged between 5 and 12 depending on the genomic group of Musa, for instance ABB (5 to 9 cycles), AAB ( 7 to 11), AAA (8 to10), AAA-h (10 to 12) and AA (9 to 14).

The high proliferation of multiple meristems obtained from CIEN-BTA-03 in TI25 (Table 1) may be ascribed to the

Table 2. Mean percentages of scalps with primary somatic embryos (PSE), embryogenic calluses (EC), nodular nonembryogenic (NNEC) or compact (CNEC) calluses from CIEN-BTA-03 banana, after 5 months of embryogenesis induction and in relation to the scalp-induction treatment.

\begin{tabular}{|c|c|c|c|c|c|c|}
\hline Treatment & Conditions & BA/IAA (mg L & PSE* & $\begin{array}{c}\text { EC } \\
\text { (\%) }\end{array}$ & $\begin{array}{c}\text { NNEC } \\
\text { (\%) }\end{array}$ & $\begin{array}{c}\text { CNEC } \\
\text { (\%) }\end{array}$ \\
\hline TI25 & $\begin{array}{c}\text { Temporary immersion (4 months) } \\
\text { + solid (2 months) }\end{array}$ & $25 / 0.217$ & 2.9 & $3.6^{(1)}$ & 97.1 & 0 \\
\hline TI22 & $\begin{array}{c}\text { Temporary immersion (4 months) } \\
\text { + solid (2 months) }\end{array}$ & $22.7 / 0.192$ & 0 & 0 & 96.4 & 0 \\
\hline ME25 & Solid medium (16 months) & $25 / 0.217$ & 0 & 0 & 99.1 & 0.9 \\
\hline ME22 & Solid medium (16 months) & $22.7 / 0.192$ & 0 & 0 & 97.3 & 2.7 \\
\hline
\end{tabular}

${ }^{(1)}$ After 3.5 months of growth. 
ECS II

a

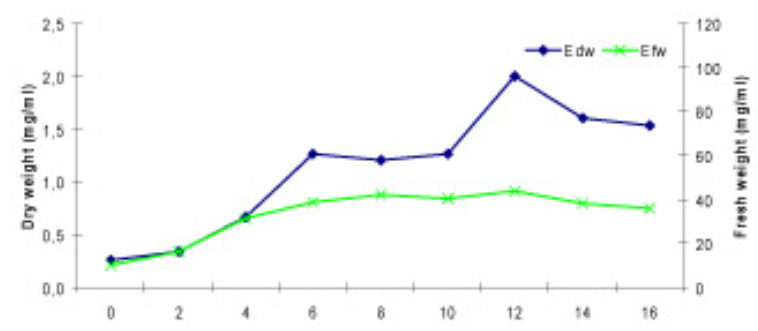

b
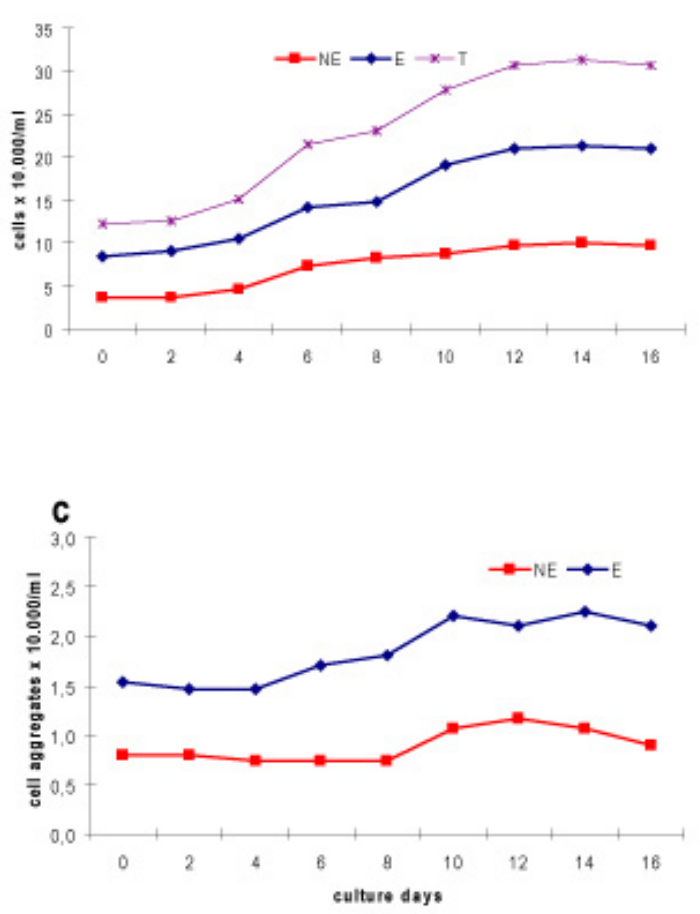

NECS II
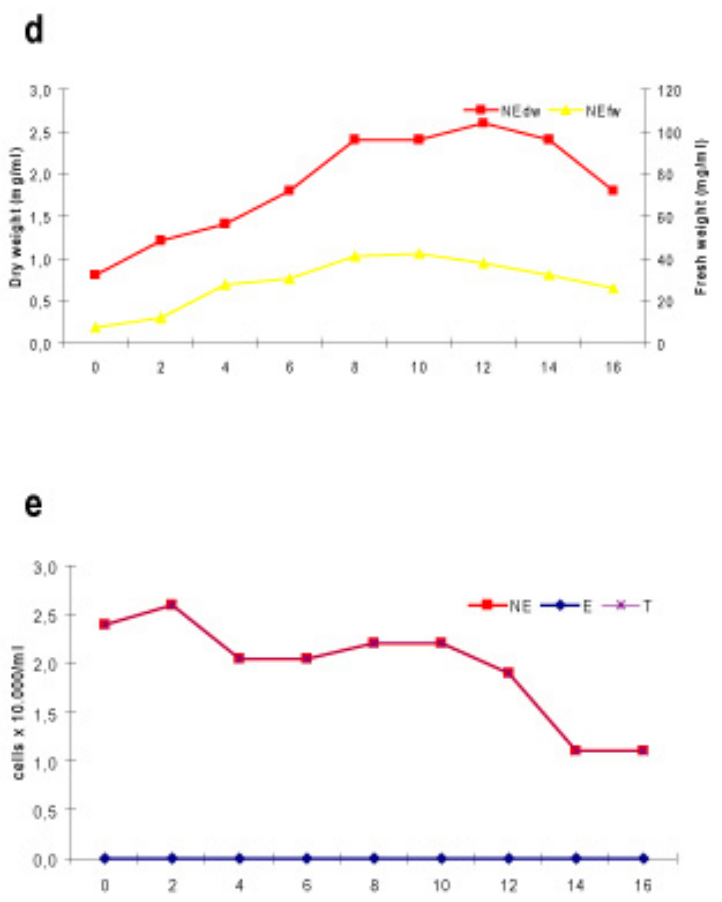

$f$

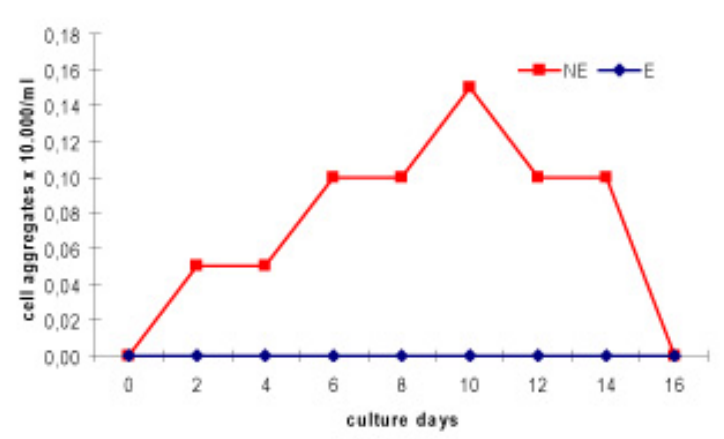

Figure 3. Growth kinetics in the embryogenic and non-embryogenic cell suspensions II of the CIEN-BTA-03 banana throughout 16 days of culture. E: embryogenic; Edw: E dry weight; Efw: E fresh weight; NE: non-embryogenic; NEdw: NE dry weight; NEfw:, NE fresh weight; T: totals.

increased sensibility of the tissues to higher concentrations of BA and IAA, together with the temporary immersions. Also, both these growth regulators may modify physiological and developmental processes. The addition of these compounds to the media, keeping a high cytokinin/auxin ratio rises the rates of cell divisions, leading to the production of multiple meristems, as already stated by Zaffari et al. (2000), and those tissues (i.e., the scalps) are embryogenically more competent (Strosse et al. 2006).
After four months the shoot apexes subjected to temporary immersion with the highest concentrations of BA $\left(25 \mathrm{mg} \mathrm{L}^{-}\right.$ $\left.{ }^{1}\right)$ and IAA $\left(0.217 \mathrm{mg} \mathrm{L}^{-1}\right)$ (TI25 treatment) grew the largest number of shoots per explants $(\sim 73)$, of which about $30 \%$ developed multiple meristems at their base. The subsequent culture of the upper portions of those meristems in the same solid media for a further two months led to the proliferation of meristems of smaller sizes (1 to $3 \mathrm{~mm}$ ) (Figure 1a; Figure 1b; Figure 1c; Figure 1 d; Figure 1e), in tight masses with few rhizome and little foliar tissue, very convenient 
for their transfer to the somatic embryogenesis-induction media.

Regarding the explants initiated in solid media (ME22 or ME25), it must be pointed out that over the first four monthly subcultures each explant formed three to five shoots, and occasionally some of them showed few multiple meristems at their base, of variable size (from 4 to $10 \mathrm{~mm}$ ). The subsequent bimonthly subcultures of these tissues in solid media showed a tendency to decrease the numbers of shoots and to increase those of small multiple meristems, particularly towards the end of the 16-month experimental period (Figure 1f; Figure 1g).

\section{Induction of somatic embryogenesis}

After three months of culture all the scalps grown in the embryogenesis-induction media developed nodular calluses which initially looked like creamy-yellow globular structures of 1 to $2 \mathrm{~mm}$ with a smooth and slack appearance; they grew in size and after five months they showed some areas with rough surfaces due to the formation of round hyaline cells (Figure 1h). Between 96 to $99 \%$ of the scalps, from all treatments, showed nodular calluses, against 0.9 to $2.7 \%$ of compact ones (Table 2), which showed many round hyaline cells on their periphery (Figure 1i).

Only the scalps coming from four months of temporary immersion and two months of solid medium (i.e., TI25), grown in the embryogenesis-induction medium, developed $3,6 \%$ of scalps with primary somatic embryos (roughly 8 to 10 ) at 3.5 months (Figure 1j; Figure 1k). Afterwards, these developed embryogenic calluses, creamy-white and with loose granular structure with numerous somatic embryos (55 embryos $\mathrm{cm}^{-2}$ ) on their periphery, mainly scutellar stage, and easily excised (Figure 11; Figure 1m). After five months, $2.9 \%$ of the scalps showed embryogenic calluses. This percentage and the features of such calluses, those of the nodular ones and those of the tight small multiple meristems obtained from CIEN-BTA-03 all fall within the ranges and descriptions published for other banana variants (Strosse et al. 2006).

\section{Establishment and maintenance of cell suspensions}

The ECSs I and II showed abundant embryogenic cells, and embryogenic aggregates (Figure 2; Figure 3). The high numbers of the latter in both suspensions may signify their high morphogenic competence and embryogenic potential (Houllou et al. 2005), which was evidenced by the high number of secondary somatic embryos obtained (Figure 1r; Figure 1s).

The embryogenic cells were usually small (1.523-2.535 $\left.\mu \mathrm{m}^{2}\right)$, round $(44 \mu \mathrm{m})$ or ovoidal $(45.5 \mu \mathrm{m} \times 68 \mu \mathrm{m})$, with a dense cytoplasm and a thick wall and a large nucleus

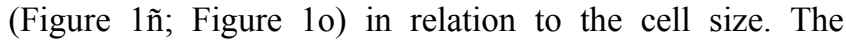
embryogenic cell aggregates were represented mainly by cell masses with conspicuous embryogenic cells on their surface (Figure $1 \mathrm{n}$ ). They ranged between 63.6 and $182 \mu \mathrm{m}$ in diameter at 12 days of growth but this increased to 550 $\mu \mathrm{m}$ after two months (Figure 1n). The non-embryogenic cells were larger than the others $\left(23.141 \mu \mathrm{m}^{2}\right)$, had diverse shapes, predominantly elongated (133.5 x $327.3 \mu \mathrm{m}$; Figure 1q) with little cytoplasmic contents, thin cellular walls, a large vacuole and a small nucleus. The described features of different cell types agree with those reported by other studies (Grapin et al. 2000; Jalil et al. 2003; Houllou et al. 2005; Quiroz et al. 2006).

After two months of the start of ECS I with 10 to 15 somatic embryos in $5 \mathrm{ml}$ of multiplication medium, they generated $4.6 \%$ of SCV and embryogenic cells $(283.000$ $\left.\mathrm{ml}^{-1}\right)$, embryogenic cell aggregates $\left(51.200 \mathrm{ml}^{-1}\right)$, nonembryogenic cells $\left(101.000 \mathrm{ml}^{-1}\right)$ or aggregates $\left(19.300 \mathrm{ml}^{-}\right.$ ${ }^{1}$ ), of which the first kinds of cell aggregates predominated (Figure 1n and Figure 2). After twelve days in ECS II, run from ECS I, the following values were recorded: embryogenic cells $\left(210.000 \mathrm{ml}^{-1}\right)$ and aggregates $(21.000$ $\left.\mathrm{ml}^{-1}\right)$, non-embryogenic cells $\left(97.300 \mathrm{ml}^{-1}\right)$ and aggregates $\left(11.600 \mathrm{ml}^{-1}\right)$ (Figure 3a; Figure 3b; Figure 3c).

The growth kinetics of the ECS II, expressed in terms of changes of fresh and dry weights, number of cells and embryogenic aggregates per $\mathrm{ml}$, showed three distinctive

Table 3. Mean numbers of mature embryos (ME) per $\mathrm{ml}$ of sedimented cells and embryogenic aggregates from embryogenic cell suspensions, the percentage of conversion of embryos to plants (CE) and percentage of vitroplants (VP) obtained after one month of culture of the banana CIEN-BTA-03.

\begin{tabular}{|c|c|c|c|}
\hline Suspension & ME & CE (\%) & VP (\%) \\
\hline ECS I & $201.690 \mathrm{a}$ & $80.8 \mathrm{a}$ & $92.5 \mathrm{a}$ \\
\hline ECS II & $98.120 \mathrm{~b}$ & $51.5 \mathrm{~b}$ & $86.3 \mathrm{~b}$ \\
\hline
\end{tabular}

For each variable, means followed by different small letters indicate statistically significant differences $(P<0.05)$. 
phases (Figure 3a; Figure3b; Figure 3c). A first one of lag phase with slow growth until the fourth day, possibly due to the adaptation period of the cells to the new conditions of the medium and with little or no cell division activity. This was followed by an exponential-linear phase between days 6 and 12 in which the rates of cell division rose, as evidenced by the increased weight and numbers of cells and cell aggregates (Figure 3a; Figure3b; Figure 3c). Later on, those processes slowed down after 14 days, possibly due to the depletion of nutrients in the medium. The kinetic features just described indicate that the optimum time for media replacement was centred around 12 days, as the cell suspensions would remain growing constantly until then.

The NECS I and II developed chiefly parenchymatous aggregates $(85.2$ to $276.3 \mu \mathrm{m})$ and small cells $\left(3.068 \mu \mathrm{m}^{2}\right)$, round $(28.4 \mu \mathrm{m})$ or oval $(27 \mu \mathrm{m} \times 34.1 \mu \mathrm{m})$ in shape, with several starch granules, thin walls and little cytoplasmic contents (Figure 1p) if compared with the embryogenic cells (Figure 1ñ; Figure 1o). The former also showed portions of necrotic tissue and easily visible yellow globular structures (2 to $4 \mathrm{~mm})$ with several parenchymatous cells distributed loosely on their periphery. The NECS II developed only the non-embryogenic cells and aggregates just described (Figure 1q; Figure 3d; Figure $3 \mathrm{f}$ ); no embryogenic cells or aggregates were detected in the NECSs even after four months.

Both the ECS I and II became established successfully in all cases (Figure 1r) and they remained viable and without signs of phenolization throughout 12 months, with subcultures every two months. This high rate of success may be ascribed to the fact that those suspensions were initiated with few somatic embryos without callus tissue in a small volume of media, ensuring a better uniformity of cell composition. Hence, this growth system is promisory as it could facilitate the continuous and massive production of secondary somatic embryos. Besides, this system has the advantage that together with the high rates of multiplication that enhance secondary somatic embryogenesis, it is highly repeatable, independent from the source of explants and largely efficient when considering repeated secondary embryogenesis cycles for prolonged periods (Ramakrishnan and Dutta, 2006). Contrasting with these findings, the results of comparable studies made by Strosse et al. (2006) on bananas and plantains showed a rate of success of only $30.5 \%$ to $47.8 \%$ in ECSs started from embryogenic calluses obtained from scalps.

Both 2.4-dichlorophenoxiacetic acid $\left(1 \mathrm{mg} \mathrm{L}^{-1}\right)$ and zeatin $\left(0,219 \mathrm{mg} \mathrm{L}^{-1}\right)$ were essential for the stages of embryogenesis-induction and the proliferation of somatic embryos of CIEN-BTA-03, as they favoured the formation of embryogenic calluses and large numbers of secondary somatic embryos in the liquid media, respectively. The 2.4$\mathrm{D}$ auxin is required for the totipotent expression of the competent cells to form proembryos and embryogenic cell aggregates. Also, low concentrations of this compound contribute to the organization of globular embryos
(Komamine, 2003). Likewise, cytokinins also play an important role in such processes as they modulate the induction and development of somatic embryos from several species; for instance, cytokinins seemingly promote a higher quality of somatic embryos from peas (Pisum sativum) (Kysely and Jacobsen, 1990) and the onset of maturity of those from other banana plants (Khalil et al. 2002).

\section{Maturity and conversion of embryos to plants}

One month after the transfer $1 \mathrm{ml}$ of sediment (cells and cell-aggregates) coming from ECS I into the maturationinduction medium, 201.690 mature embryos were obtained (Table 3). These embryos were elongated (1 to $2 \mathrm{~mm}$ ) (Figure 1s; Figure 1t; Figure 1u) with a smooth surface, and in many cases they showed a notorious shoot apex (Figure 1t; Figure 1u). In the ECSs II the mature embryos showed features resembling those just described but they were less (98.120). The former quantity, that is mature embryos from ECS I, falls within earlier published values for Musa spp. ( 150.000 to 470.000 embryos) (Strosse et al. 2006).

The mature embryos coming from ECS I and II growing in conversion media reached sizes ranging from 0.5 to $1.5 \mathrm{~cm}$, and showed a noticeable shoot or first foliar sheath (Figure 1v; Figure 1x; Figure 1y; Figure 1z) after one month. These embryos evolved into plants when transferred into MS plus $400 \mathrm{mg} \mathrm{L}^{-1} \mathrm{BA}$ and kept developing, emitting roots (Figure 1aa; Figure 1ab). Regarding the percentages of conversions of embryos to plants $(80.7 \%)$ and of vitroplants obtained $(92.5 \%)$ (Table 3), those values were higher for the embryos coming from ECS I than from ECS II; this might be due to the larger amounts of non-embryogenic cells and aggregates present in the latter (Figure 3b; Figure 3c). Nonetheless, the vitroplants regenerated from both cell suspensions developed normally and emitted roots.

It is noteworthy to point out that our percentages of embryo conversions and of obtained vitroplants are appreciably higher than values found in other bananas (42.5 to 55.5\%), starting from scalp embryogenic calluses (Xu et al. 2005). Our results reflect the high quality and the adequate composition of the cell suspensions, as well as the improved efficiency of the described procedures.

\section{CONCLUDING REMARKS}

The culture of shoot apexes during four months under temporary immersion and thereafter two months in solid media containing $25 \mathrm{mg} \mathrm{L}^{-1} \mathrm{BA}$ and $0.217 \mathrm{mg} \mathrm{L}^{-1}$ IAA (i.e., treatment TI25) reduced the timespan required for the induction of meristems and increased the production of small scalps. These facilitated the obtainment of embryogenic calluses with abundant somatic embryos, which in turn were highly competent embryogenically for the establishment of embryogenic cell suspensions. The latter produced a large number of embryogenic cell aggregates very suitable for the development of the 
subsequent stages of maturity and conversion of secondary embryos to plants. The growth kinetics of such embryogenic cell suspensions showed that the optimum period for media replacement is in the order of about 12 days.

Further, this work also showed that the production time of embryogenic scalps from the tetraploid somaclonal variant CIEN-BTA-03 of the Cavendish subgroup, grown in TI25, can be reduced to six months, appreciably less than the values reported (8-14 months) for other tetraploids of this subgroup by other authors (Strosse et al. 2006). Hence, the treatment TI25 appears to be a useful alternative for the production of large numbers of multiple meristems within a timespan of six months with a single subculture, as lesser of these decrease production costs. These procedures represent a very effective method for the obtainment pf somatic embryos, based on its high production of mature somatic embryos per unit volume of medium and high embryo-toplant conversion rates.

\section{REFERENCES}

Agrocadenas. Información mundial. Producto bananos. Ministerio de Agricultura y Desarrollo Rural. Observatorio Agrocadenas Colombia, 2005. Update February 2006. [cited 10 June 2008] Available from Internet: http://www.agrocadenas.gov.co/banano/reportes.htm.

CABONI, E.; ANGELI, D.; CHIAPPETTA, A.; INNOCENTI, A.; VAN ONCKELEN, H. and DAMIANO, C. Adventitious shoot regeneration from vegetative shoot apices in pear and putative role of cytokinin acumulation in the morphogenetic process. Plant Cell Tissue and Organ Culture, August 2002, vol. 70, no. 2, p. 199-206.

CHOI, Y.; KO, S. and YOON, S. Production of plantlets of Eleutherococcus sessiliflorus via somatic embryogenesis and successful transfer to soil. Plant Cell Tissue and Organ Culture, May 2002, vol. 69, no. 2, p. 201-204.

FILIPPI, S.; APPEDAZZATO, B. and RODRÍGUEZ, A. Variações morfológicas de embriões somáticos obtidos a partir de inflorescencias de bananeira. Scientia Agricola, October, 2001, vol. 58, no. 4, p. 711-716.

GIMÉNEZ, C.; DE GARCÍA, E.; ENRECH, X. and BLANCA, I. Somaclonal variation in banana: citogenetic and molecular characterization of the somaclonal variant CIEN BTA-03. In vitro Cellular and Developmental Biology-Plant, March 2001, vol. 37, no. 2, p. 217-222.

GRAPIN, A.; ORTÍZ, J.; LESCOT, T.; FERRIÈRE, N. and CÔTE, F. Recovery and regeneration of embryogenic cultures from female flowers of False Horn Plantain. Plant Cell Tissue and Organ Culture, June 2000, vol. 61, no. 3, p. 237-244.

HOULLOU, L.; KIDO, E.; FALCO, M.; SILVA, M.; VARGAS, A.; NOGUEIRA, N.; LANZONI, M. and
TULMAN, A. Somatic embryogenesis and the effect of particle bombardment on banana Maçã regeneration. Pesquisa Agropecuária Brasilera, November 2005, vol. 40, no. 11, p. 1081-1086.

JALIL, M.; KHALID, N. and OTHMAN, R. Plant regeneration from embryogenic suspension cultures of Musa acuminata cv Mas (AA). Plant Cell Tissue \& Organ Culture, December 2003, vol. 75, no. 3, p. 209-214.

KHALIL, S.; CHEAH, K.; PEREZ, E.; GASKILL, D. and HU, J. Regeneration of banana (Musa spp. AAB cv. Dwarf Brazilian) via secondary somatic embryogenesis. Plant Cell Report, June 2002, vol. 20, no. 12, p. 1128-1134.

KOMAMINE, A. My way with plant cell cultures: significance of experimental systems in plant biology. In vitro Cellular and Developmental Biology-Plant, March 2003, vol. 39, no. 2, p. 63-74.

KUO, H.; CHEN, J. and CHANG, W. Efficient plant regeneration through direct somatic embryogenesis from leaf explants of Phalaenopsis "Little steve". In vitro Cellular and Developmental Biololgy-Plant, July 2005, vol. 41, no. 4, p. 453-456.

KYSELY, W. and JACOBSEN, H. Somatic embryogenesis from pea embryos and shoot apices. Plant Cell, Tissue and Organ Culture, January 1990, vol. 20, no. 1, p. 7-14.

MARTINELLI, L.; CANDIOLI, E.; COSTA, D. and POLETTI, V. Morphogenic competence of Vitis rupestris S. secondary somatic embryos with a long culture history. Plant Cell Report, June 2001, vol. 20, no. 4, p. 279-284.

MOREL, G. and WETMORE, R. Tissue culture of monocotyledons. American Journal of Botany, February 1951, vol. 38, no. 2, p. 138-140.

MURASHIGE, T. and SKOOG, F. A revised medium for rapid growth and bioassays with tobacco tissue. Physiologia Plantarum, July, 1962, vol. 15, no. 3, p. 473497.

PÉREZ, C. Técnicas Estadísticas con SPSS 12. Aplicaciones al análisis de datos. Madrid. Editorial Pearson Prentice Hall, Pearson Educación, S.A., 2005. 802 p. ISBN 84-205-4410-8.

PÉREZ, J. and ROSSEL, P. Inflorescence proliferation for somatic embryogenesis induction and suspension-derived plant regeneration from banana (Musa AAA, cv. 'Dwarf Cavendish') male flowers. Plant Cell Reports, June 2008, vol. 27 , no. 6, p. 965-971.

QUIROZ, F., ROJAS, R. and LOYOLA, V.. Embryo production through somatic embryogenesis can be used to study cell differentiation in plants. Plant Cell, Tissue and Organ Culture, September 2006, vol. 86, no. 3, p. 285-301. 
RAMAKRISHNAN, N. and DUTTA, G. High-frequency plant regeneration through cyclic secondary somatic embryogenesis in black pepper (Pipper nigrum L.). Plant Cell Report, January 2006, vol. 24, no. 12, p. 699-707.

STROSSE, H.; SCHOOFS, H.; PANIS, B.; ANDRE, E.; REYNIERS, K. and SWENNEN, R. Development of embryogenic cell suspensions from shoot meristematic tissue in bananas and plantains (Musa spp.). Plant Science, January 2006, vol. 170, no. 1, p. 104-112.

TRUJILLO, I.; DE GARCÍA, E. and HADDAD, O. Epidemiological studies of yellow sigatoka (Mycosphaerella musicola) disease in micropropagated Musa clones. Acta Horticulturae, September 1998, vol. 490 , no. 1, p. 345-352.

UNAI, E.; TRUJILLO, I. and DE GARCÍA, E. Comparison of characteristics of banana (Musa sp.) from the somaclone CIEN-BTA-03 and its parental clone Williams. Fruits, July 2004, vol. 59, no. 4. p. 257-263.

VIDAL, M. and DE GARCÍA, E. Analysis of a Musa sp. somaclonal variant resistant to yellow sigatoka. Plant Molecular Biology Reporter, March 2000, vol. 18, no. 1, p. 23-31.

XU, C.; PANIS, B.; STROSSE, H.; LI, H.; XIAO, H.; FANS, H. and SWENNEN, R. Establishment of embryogenic cell suspensions and plant regeneration of the dessert banana 'Williams'(Musa AAA group). Journal of Horticultural Science \& Biotechnology, September 2005, vol. 80 , no. 5, p. 523-528.

ZAFFARI, G.; KERBAUY, G.; KRAUS, J. and ROMANO, E. Hormonal and histological studies related to in vitro banana bud formation. Plant Cell, Tissue \& Organ Culture, December 2000, vol. 63, no. 3, p. 187-192. 